\title{
Soil Organic Carbon Stock in Natural and Human Impacted Ecosystems of Senapati District, Manipur
}

\author{
Ng Niirou', Asha Gupta ${ }^{2}$, Th. Binoy Singh ${ }^{3}$ \\ Centre of Advanced study in Life Sciences, Manipur University, Canchipur, 795003, India
}

\begin{abstract}
The present study was carried out to estimate the soil organic carbon stocks (SOC) under different land uses of Senapati district, Manipur. The natural Undisturbed mixed Oak Forest (UOF) which was dominated by Quercus serrata and co-dominated by Lyonia ovalifolia, Disturbed mixed oak forest (DOF) dominated by Quercus serrata and co-dominated by Quercus griffithii, Pinus kesiya Plantation Forest (PPF) and Orchard Plantation Forest (OPF) dominated by Mangifera indica and co-dominated by Prunus domestica with their corresponding GPS co-ordinates located between $25^{\circ} 12.067^{\prime} \mathrm{N}$ to $25^{\circ} 12.145^{\prime} \mathrm{N}$ and $93^{\circ} 59.915^{\prime} \mathrm{E}$ to $94^{\circ} 02.296^{\prime} \mathrm{E}$ and at the elevation of 1146-1254 m msl. Soil organic carbon stock was estimated upto $30 \mathrm{~cm}$ soil depth and maximum SOC stock was found in UOF followed by DOF, OPF and least SOC stock was recorded under the PPF with mean SOC stock value $55.46 t$ ha ${ }^{-1}, 53.34 t$ $\mathrm{ha}^{-1}, 53.26 \mathrm{tha}^{-1}$ and $42.72 \mathrm{tha}^{-1}$ respectively. In all the different land uses the percentage SOC content decreased with increased in soil depths. The depth wise distribution of the estimated SOC stock under different ecosystems showed highest amount in the surface soil layer (0-10 cm) than the subsurface soil layers. Soil layer 0-10 cm contributes $42.65 \%, 41.14 \%, 41.49 \%$ and $39.98 \%$ in UOF, DOF, $P P F$ and $O P F$ respectively. SOC showed negative correlation with soil bulk density and pH but positive correlation with soil temperature and moisture. The naturally occurring mixed oak forest sequesters more carbon in the soils than the pine plantation forest. On the other hand Orchard plantation also plays a potential role in capturing large amount of carbon into the soil. Thus our finding highlights the future strategy of protecting and conserving the existing Secondary mixed Oak forest and substituting Orchard plantation in place of large coniferous plantations in Senapati district, Manipur.
\end{abstract}

Keywords: Soil, Secondary forest, Oak, Orchard, Plantation, Coniferous

\section{Introduction}

Increased emission of $\mathrm{CO}_{2}$ and other greenhouse gases in the atmosphere has become the most threatening factor leading to global warming and climate change. Soil represents one of the third largest carbon sink after ocean and geologic sinks. Emissions of carbon due to land use and land cover change (LULCC) is the second largest anthropogenic source next to burning of fossil fuel (IPCC, 2007) affecting the carbon flow and carbon cycle in the terrestrial ecosystem. In the last decade, the greenhouse effect has been of great concern and has led to the studies on quality, kind, distribution pattern and behaviour of SOC in different parts of the world. Soil being the largest pool of organic carbon in the terrestrial ecosystem has a large impact on atmospheric $\mathrm{CO}_{2}$ concentration hence any change in SOC storage will alter the carbon cycle (Xu et al. 2011). The reservoir of soil carbon acts as a significant source or sink of the atmospheric $\mathrm{CO}_{2}$ in response to global warming (Trumbore, 1997). The accumulation of carbon continues until the carbon gain from photosynthesis is larger than respiration losses (Jandl et al. 2007). A better understanding of SOC and flows is essential for better carbon management and climate change mitigation options and help global circulation models used to guide climate policy (Scharlemann et al. 2014). Assessment of soil organic carbon requires interdisciplinary work input from remote sensing scientists, ecologists, agronomists, earth system modellers' special analysts, geographers, land-use planners and others ( Scharlemann et al. 2014) and the policy makers need to recognize the potential importance of SOC in the global carbon flow and carbon cycle to mitigate climate change. $\mathrm{CO}_{2}$ released by soil respiration is more than ten times released from the fossil fuel burning (Raich and Potter, 1995) acting as large source of carbon into the atmosphere. SOC and its various fractions vary significantly under different forest categories and understanding these variations are important for assessing the carbon balance and dynamics of this system as these factors will depict the extent of forest vulnerability to sink and source of carbon (Shreekanth et al. 2013). The terrestrial C stock of boreal comprises $85 \%$, temperate $60 \%$ and tropical rainforest $50 \%$ (Dixon et al. 1994). Therefore, the study of SOC stock in some selected land use sector has been one of the key interests in the present research field so as to expand the limited information available in the existing condition to contribute in the climate change issue or defer global warming. According to IPCC (2000) conversion of tropical rain forest into agricultural ecosystems and deforestation released 1.6 to 1.7 Pg C /year. Chhabra and Dhadwal (2004) have estimated the total soil organic pool in Indian forest up to top $1 \mathrm{~m}$ depth was $6.8 \mathrm{Pg} \mathrm{C}$, using estimated soil organic carbon densities and Remote Sensing (RS) based area by forest types. Land use changes and land management practices have a great influence on the amount of $\mathrm{C}$ sequestered in the soil (Lal, 2004; FAO, 2005). Soil C sequestration as a result of afforestation/reforestation activities can both increase or decrease SOC depending on the local condition such as land history, type of tree species, soil types, site preparation and climate (Laganiere et al. 2010). According to Lal, (2005) the rate of SOC sequestration, and the magnitude and the quality of soil carbon stocks depend on the complex interaction between climate, soils, tree species and management, and chemical composition of the litter as determined by the dominant species and has relative impact of climate and topography on SOC stocks (Campos et al. 2014). Dixon et al. (1994) reported that two thirds of the terrestrial carbon in forest ecosystem is contained in soils. Soil organic carbon plays a very important role as a key indicator of soil quality and soil productivity. With increase in soil depth, the relative importance in controlling SOC in all land uses decreases 


\section{International Journal of Science and Research (IJSR) ISSN (Online): 2319-7064 \\ Index Copernicus Value (2015): 78.96 | Impact Factor (2015): 6.391}

(Albaladej et al. 2013). Soil carbon lost is reported due to deforestation, whereas regenerating forests may sequester carbon both in biomass and soils. Carbon stocks are closely related to the decay rates within the carbon cycle and to the quantity and quality of the carbon input (Tate et al. 2000). Land use conversion from or into forest ecosystem can affect SOC stock to $1 \mathrm{~m}$ or more often to $2 \mathrm{~m}$ depth (Lal, 2005). The estimation of soil organic carbon losses and gains are subjected to large errors and methodological biases (Houghton 2005). Soils under natural vegetation had a higher SOC content in soil compared to cultivated soil (Shrestha et al. 2004) but secondary forests and mixed plantation forest also prevents SOC losses and act as sustainable land use (Chiti et al. 2014). Hence the present study was conducted to estimate the soil carbon stock in different land use categories in Senapati district, Manipur.

\section{Material and Methods}

\section{Study area}

The present study was conducted in Senapati district. Three study sites (Fig.1) were demarcated at Thangal Ecological Park viz. Undisturbed Oak forest (UOF) (latitude $25^{\circ} 12^{\prime} .113$ 'N, longitude 9359'.900'E, elevation 1,192 m a.s.l), Pine Plantation Forest (PPF) (latitude $25^{\circ} 12^{\prime} .088^{\prime \prime} \mathrm{N}$, longitude $93^{\circ} 59^{\prime} .828^{\prime \prime}$ E, elevation 1, $146 \mathrm{~m}$ a.s.l), Disturbed Oak Forest (DOF) (latitude 25 $12^{\prime} .067^{\prime} \mathrm{N}$, longitude 9359'.915'E, elevation 1, $218 \mathrm{~m}$ a.s.l). One site was selected at Tunggam TNK village hill (Fig.1) Orchard Plantation Forest (latitude $25^{\circ} 16^{\prime} .145^{\prime} \mathrm{N}$, longitude $94^{\circ} 02^{\prime} .296^{\prime \prime} \mathrm{E}$, elevation $\left.1,245 \mathrm{~m} \mathrm{~m} . \mathrm{s} .1\right)$ privately owned (Table-1). The three forests are community forests belonging to Mayangkhang people of Manipur during 2015-2016. The pine forest stand constitute plantation is well-protected, 3040 years old exclusively covered by Pinus kesiya. The forest is classified as montane or hill forest of Manipur (Champion and Seth 1968). The study site received an average annual rainfall of $1754.05 \mathrm{~mm}$ during the study period. The average monthly temperature varied from a maximum of $30.0^{\circ} \mathrm{C}$ in the month of July to a minimum $4.1^{\circ} \mathrm{C}$ in December.
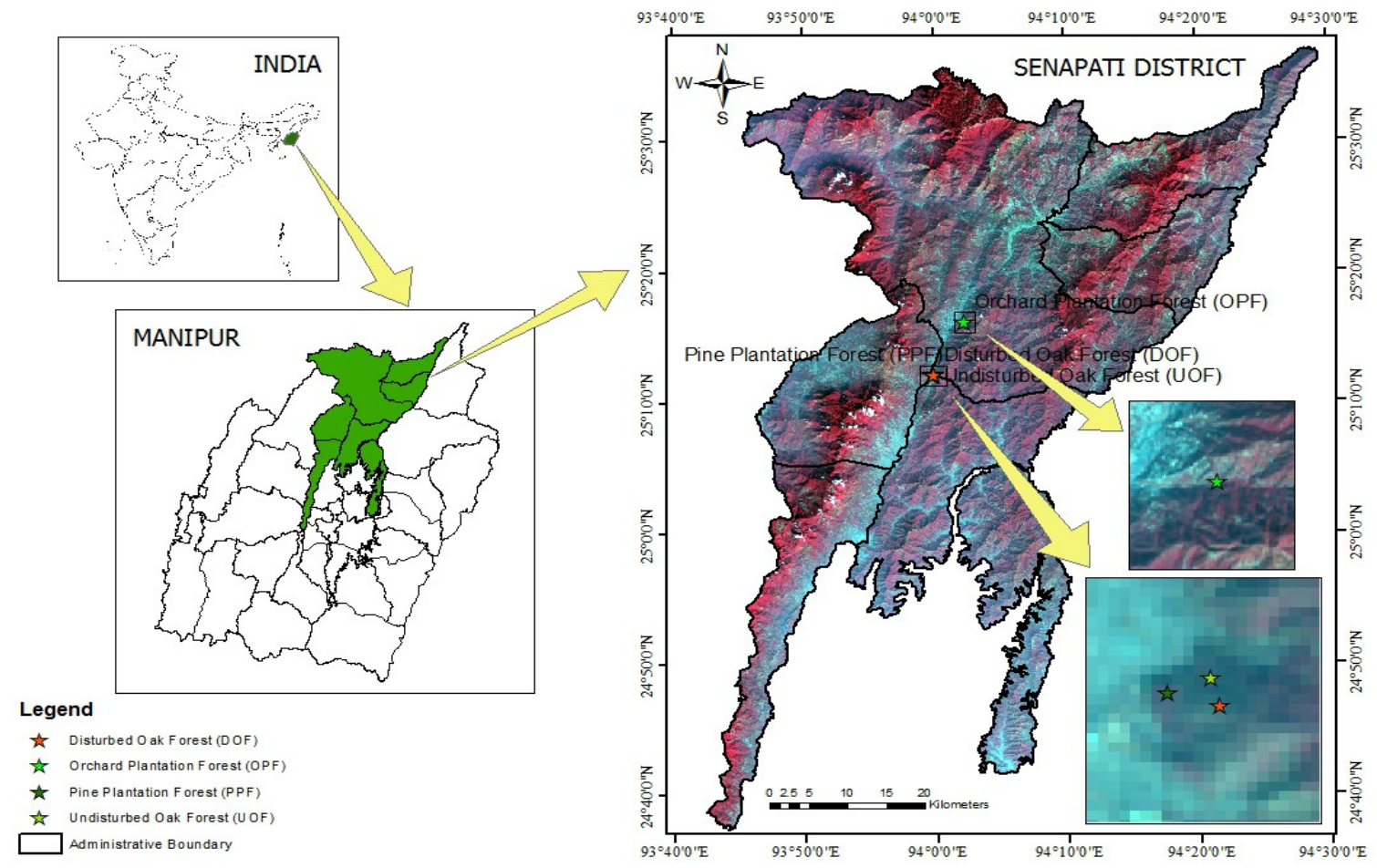

Figure 1: Map showing the location of the study sites in Senapati District, Manipur

Table 1: Sampling sites and their characteristic features

\begin{tabular}{|c|c|c|}
\hline $\begin{array}{c}\text { Land use } \\
\text { Category }\end{array}$ & Characteristics features & Ownership \\
\hline $\begin{array}{c}\text { Undisturbed } \\
\text { Oak forest }\end{array}$ & $\begin{array}{c}\text { Well conserved at present, having } \\
\text { disturbance history. Quercus } \\
\text { serrata, Lyonia ovalifolia }\end{array}$ & $\begin{array}{c}\text { Community } \\
\text { forest }\end{array}$ \\
\hline $\begin{array}{c}\text { Disturbed Oak } \\
\text { forest }\end{array}$ & $\begin{array}{c}\text { Facing slight biotic pressure, } \\
\text { Quercus serrata, Quercus griffithii }\end{array}$ & $\begin{array}{c}\text { forest } \\
\text { formity }\end{array}$ \\
\hline $\begin{array}{c}\text { Pine plantation } \\
\text { forest }\end{array}$ & Pinus kesiya plantation. & $\begin{array}{c}\text { Community } \\
\text { forest }\end{array}$ \\
\hline $\begin{array}{c}\text { Orchard } \\
\text { plantation }\end{array}$ & $\begin{array}{c}\text { Orchard plantation. Mangifera } \\
\text { indica, Prunus domestica. }\end{array}$ & $\begin{array}{c}\text { Private } \\
\text { forest }\end{array}$ \\
\hline
\end{tabular}

\section{Soil Analysis}

The estimation of soil carbon stock in different land uses in Senapati district was undertaken through the estimation of soil organic carbon. In each of the different land uses soil sample were collected from each land use types on monthly basis over a period of one year. Soils were collected randomly at five points from each forest types at three different depths $(0-10 \mathrm{~cm}, 10-20 \mathrm{~cm}, 20-30 \mathrm{~cm})$ using soil corer. Soil samples were made composite by thorough 


\section{International Journal of Science and Research (IJSR) ISSN (Online): 2319-7064 \\ Index Copernicus Value (2015): 78.96 | Impact Factor (2015): 6.391}

mixing. Fresh soil samples were used for analysing the moisture content. The remaining soils were air dried, sieved through $2 \mathrm{~mm}$ sieve and kept it for analysis of soil organic carbon, available nitrogen, available phosphorous and available potassium, soil $\mathrm{pH}$.

Bulk density and soil porosity were determined following Anderson and Ingram (1993) following the formulae:

Bulk density $\left(\mathrm{g} / \mathrm{cm}^{3}\right)=\left(\mathrm{W}_{2}-\mathrm{W}_{1}\right) / \mathrm{V}$

Where, $\mathrm{W}_{2}$ and $\mathrm{W}_{1}=$ fresh and dry weights of soil, $\mathrm{V}=$ volume of the metal corer

Total porosity was calculated from the bulk density of soil and particle density (assuming it to be $2.65 \mathrm{~g} / \mathrm{cm}^{3}$ for mineral soils)

Total porosity $(\%)=\{1-$ (bulk density/particle density) $\mathrm{X}$ 100.

Soil texture was determined by soil hydrometer method. Soil $\mathrm{pH}$ was determined using digital soil $\mathrm{pH}$ meter. Available Nitrogen in soil was determined by boric acid method (Subiah and Asija, 1956). Available Phosphorous by following (Bray and Kurtz, 1945) and available Potassium by following Hanway and Heidel (1952) were determined.

Soil organic carbon was determined following Walkley and Black (1934). 1 gram of oven dried soil sample was placed in a $500 \mathrm{ml}$ flask and $10 \mathrm{ml} 1 \mathrm{~N}$ potassium dichromate $\left(\mathrm{K}_{2} \mathrm{Cr}_{2} \mathrm{O}_{7}\right)$ was added. $20 \mathrm{ml}$ of concentrated (98\%) sulphuric acid $\left(\mathrm{H}_{2} \mathrm{SO}_{4}\right)$ was added and the flask was swirled for thoroughly mixing the soil and reagents. After half an hour $200 \mathrm{ml}$ distilled water was added to the solution which is followed by addition of $10 \mathrm{ml}$ Ortho Phosphoric acid $\left(\mathrm{H}_{3} \mathrm{PO}_{4}\right)$ and $1 \mathrm{ml}$ of diphenylamine $\left(\left(\mathrm{C}_{6} \mathrm{H}_{5}\right)_{2} \mathrm{NH}\right)$ indicator. The undigested dichromate was determined by titrating against $0.5 \mathrm{~mol} \mathrm{l}^{-1}(0.5 \mathrm{~N})$ ferrous ammonium sulphate $(\mathrm{Fe}$ $\left.\left(\mathrm{NH}_{4}\right)_{2}\left(\mathrm{SO}_{4}\right)_{2} \cdot \mathrm{H}_{2} \mathrm{O}\right)$. Percentage SOC concentration was estimated using the following equation:
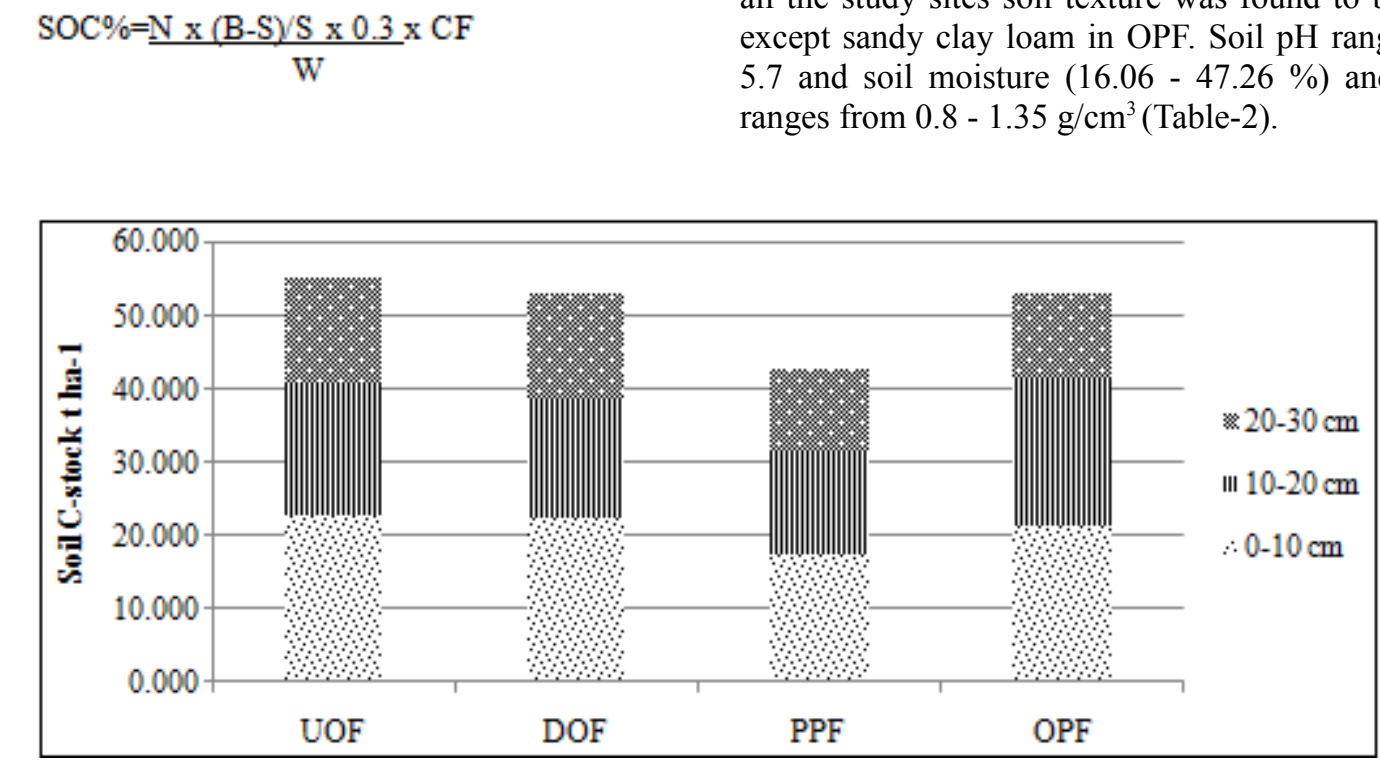

Figure 2: Depth wise distribution of Soil C-stock of different forest categories (Undisturbed mixed Oak Forest (UOF),

Disturbed mixed Oak forest (DOF), Pinus kesiya Plantation Forest (PPF) and Orchard Plantation Forest (OPF)
Where, $\mathrm{N}=$ normality of the $\mathrm{Fe}\left(\mathrm{NH}_{4}\right)_{2}\left(\mathrm{SO}_{4}\right)_{2} \cdot \mathrm{H}_{2} \mathrm{O}$ solution (from blank titration),

$\mathrm{B}=$ volume $(\mathrm{ml})$ required in blank titration,

$\mathrm{S}=$ volume required in actual titration,

$\mathrm{W}=$ weight $(\mathrm{g})$ of oven-dried soil sample and

$\mathrm{CF}=$ correction factor set by Walkley and Black (1.32 considering recovery of $76 \%$ ).

The amount of soil carbon stock per hectare was obtained considering soil depth $(\mathrm{cm})$, bulk density $\left(\mathrm{g} \mathrm{cm}^{-3}\right)$ and the percentage of soil organic carbon content (SOC).

\section{Statistical analysis}

One-way ANOVA and Pearson Correlation were employed to test the significant difference between the different land uses, soil depths, seasons using SPSS 11.0.

\section{Results and Discussion}

The degree of human interference on different land uses has a tremendous effect on the soil organic carbon content. In all the study sites SOC upto the soil depth $0-30 \mathrm{~cm}$ ranges between $0.86 \%-2.51 \%$ (Table-2). Soil organic carbon stock ranges from $52.713 \mathrm{t} \mathrm{ha}^{-1}$ to $58.646 \mathrm{t} \mathrm{ha}^{-1}$ in UOF in spring and rainy season respectively. In DOF, SOC stock ranges from $50.45 \mathrm{t} \mathrm{ha}^{-1}$ to $57.45 \mathrm{tha}^{-1}$ in spring and rainy season. In OPF the soil carbon stock ranges from $46.48 \mathrm{tha}^{-1}$ to $53.49 \mathrm{t}$ $\mathrm{ha}^{-1}$ in winter and rainy season respectively and in PPF the soil carbon stock ranges from $40.68 \mathrm{t} \mathrm{ha}^{-1}$ (spring) to $45.89 \mathrm{t}$ $\mathrm{ha}^{-1}$ (summer). In all the different land uses the highest soil organic carbon was observed in surface soil layer, $0-10 \mathrm{~cm}$ followed by $10-20 \mathrm{~cm}$ and least SOC content was observed in the $20-30 \mathrm{~cm}$ soil depth. In all the study sites $41.16 \%$, $42.65 \%, 41.49 \%$ and $39.98 \%$ of soil carbon stock were observed in surface layer $(0-10 \mathrm{~cm})$ for UOF, DOF, PPF and OPF respectively. The mean seasonal soil C-stock were observed in the order UOF $>$ DOF $>$ OPF $>$ PPF (Table-2). In all the study sites soil texture was found to be Sandy loam except sandy clay loam in OPF. Soil $\mathrm{pH}$ ranges from 5.035.7 and soil moisture (16.06 - 47.26\%) and bulk density ranges from $0.8-1.35 \mathrm{~g} / \mathrm{cm}^{3}$ (Table-2). 


\section{International Journal of Science and Research (IJSR) ISSN (Online): 2319-7064 \\ Index Copernicus Value (2015): 78.96 | Impact Factor (2015): 6.391}

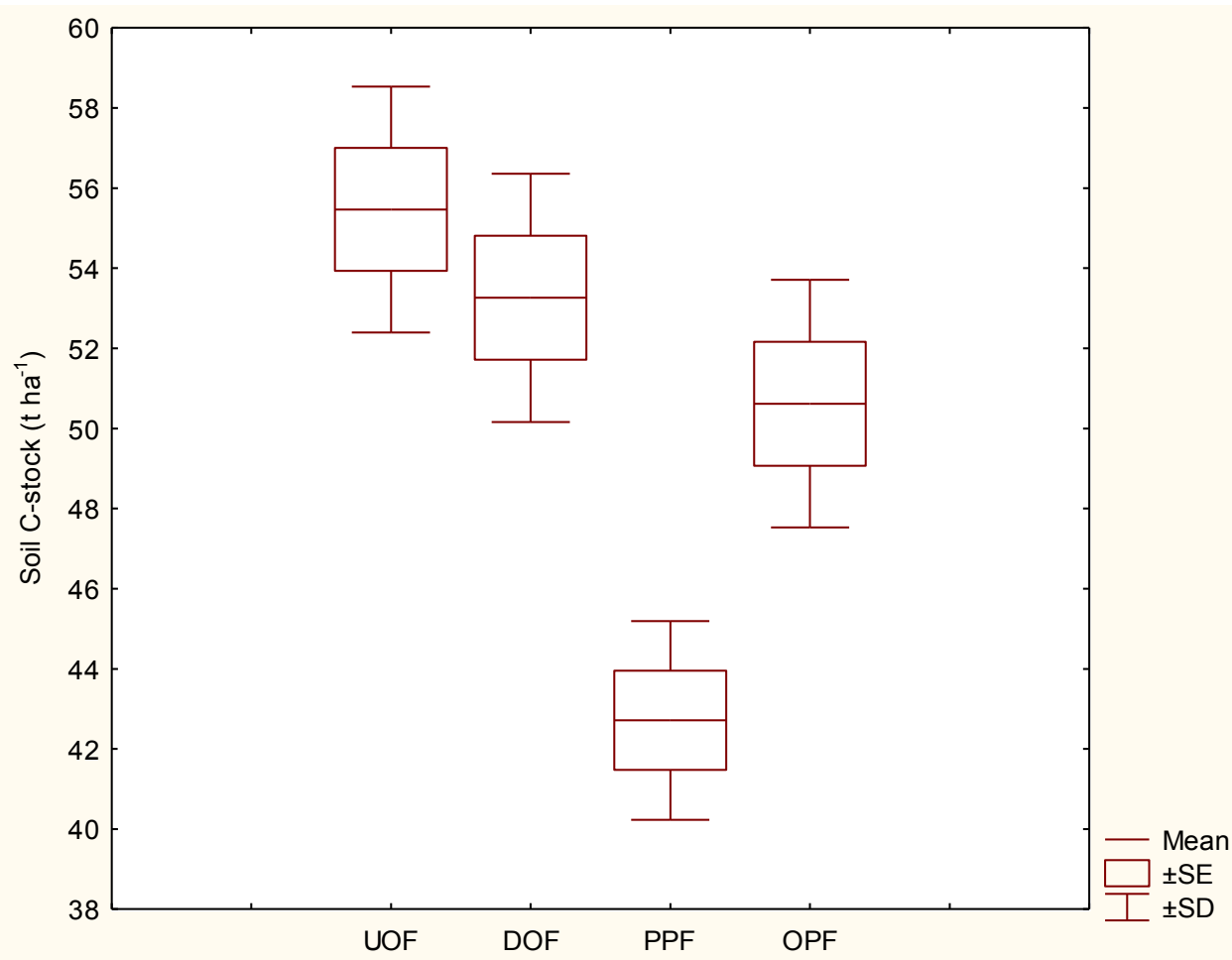

Figure 3: Box-plot depicting soil organic carbon stock in different land use of Senapati district, Manipur (Undisturbed mixed Oak Forest (UOF), Disturbed mixed Oak forest (DOF), Pinus kesiya Plantation Forest (PPF) and Orchard Plantation Forest. (OPF)

The soil carbon stock in the surface layer was largest in the UOF and least in the PPF (23.72 $\left.\mathrm{t} \mathrm{ha}^{-1} \& 18.95 \mathrm{t} \mathrm{ha}^{-1}\right)$ respectively. It is observed that $0-10 \mathrm{~cm}$ soil layer acts as better carbon sink as this layer contributes higher percentage to the total carbon stock.

Results of one-way ANOVA indicates that SOC content amongst the different land uses was not significantly different at 0.05 level $(\mathrm{F}=1.28 ; \mathrm{p}=0.283)$. The soil $\mathrm{pH}$, moisture and temperature amongst the different land uses were highly significant $(\mathrm{F}=7.8, \mathrm{~F}=6.41, \mathrm{~F}=2.74 ; \mathrm{p}<0.001)$ and SOC contents, $\mathrm{pH}$, moisture and temperature at different soil depths were highly significant $(\mathrm{F}=134.92, \mathrm{~F}=20.33$, $\mathrm{F}=28.49, \mathrm{~F}=17.42 ; \mathrm{P}<0.001)$. The $\mathrm{SOC}$ content showed negative correlation with $\mathrm{pH}(\mathrm{r}=-0.58 ; \mathrm{p}<0.00)$ but showed positive correlation with moisture $(\mathrm{r}=0.53 ; \mathrm{p}<0.001)$ but temperature was not significantly correlated $(\mathrm{r}=0.19$; $\mathrm{p}=2.31$ ) at 0.01 level.

Table 2: Soil physical and chemical properties in different land uses of Senapati district of Manipur

\begin{tabular}{|c|c|c|c|c|}
\hline \multirow{2}{*}{ Parameters } & UOF & DOF & PPF & OPF \\
\cline { 2 - 5 } & Types of land use \\
\hline $\begin{array}{c}\text { Soil bulk } \\
\text { density }\left(\mathrm{g} / \mathrm{cm}^{3}\right)\end{array}$ & $0.95-1.25$ & $1.05-1.35$ & $0.80-1.08$ & $1.1-1.34$ \\
\hline Soil texture & Sandy loam & Sandy loam & Sandy loam & $\begin{array}{c}\text { Sandy clay } \\
\text { loam }\end{array}$ \\
\hline Soil pH & $5.5-5.7$ & $5.4-5.6$ & $5.03-5.4$ & $5.3-5.6$ \\
\hline SOC \% & $0.95-2.51$ & $0.98-2.14$ & $0.95-2.36$ & $0.86-1.94$ \\
\hline $\begin{array}{c}\text { Soil } \\
\text { temperature }{ }^{\circ} \mathrm{C}\end{array}$ & $12.85-22.95$ & $14.4-23.5$ & $14.15-23.15$ & $12-23.21$ \\
\hline $\begin{array}{c}\text { Soil moisture } \\
\%\end{array}$ & $19.72-47.26$ & $17.59-39.08$ & $16.06-42.09$ & $16.45-37$ \\
\hline Soil porosity\% & $64.6-74.7$ & $55.4-67.5$ & $70.9-75.4$ & $54.8-65$ \\
\hline Soil C-stock & $52.71-58.64$ & $50.45-57.45$ & $40.64-45.87$ & $46.474-$ \\
\hline
\end{tabular}

\begin{tabular}{|c|c|c|c|c|}
\hline$\left(\mathrm{t} \mathrm{ha}^{-1}\right)$ & & & & 53.45 \\
\hline $\begin{array}{c}\text { Available } \mathrm{N} \\
\left(\mathrm{t} \mathrm{ha}^{-1}\right)\end{array}$ & $107-374$ & $104-300$ & $178-563$ & $138-421$ \\
\hline $\begin{array}{c}\text { Available } \mathrm{P} \\
\left(\mathrm{t} \mathrm{ha}^{-1}\right)\end{array}$ & $10-25$ & $11-30$ & $11-23$ & $8-30$ \\
\hline $\begin{array}{c}\text { Available K } \\
\left(\mathrm{t} \mathrm{ha}^{-1}\right)\end{array}$ & $198-596$ & $274-588$ & $354-520$ & $198-623$ \\
\hline
\end{tabular}

Measuring changes in the forest soil carbon stock is rather costly and difficult as large number of soil samples are required to detect small change in soil organic carbon stock (Palmer et al. 2002). Soil bulk density increases with depth but soil moisture decreases with increase in depth in all the sites. SOC and soil carbon stock decrease with increase in soil depth in all the land uses which is in consistent with the finding as reported by Jobbagy and Jackson (2000). Highest soil organic carbon stock was computed in the UOF followed by DOF, OPF and the least was found in the PPF. As expected, UOF had significantly higher soil carbon than other land uses implying the role of conservations in augmenting the soil carbon pool. According to our study the higher soil carbon stock in the protected oak forest may be due to increase in aboveground biomass in the forest with time after conservation as there is carbon returns to the soil in the form of litter, crop residues, manure. The lower organic carbon stock in the pine forest may be attributed to lower carbon inputs. Needle leaf conifer and broad-leaf deciduous species are commonly associated with differences in tree growth, carbon, and nutrient cycling and carbon accumulation in soils (Melvin et al. 2015). Carbon fixation via photosynthesis, and subsequent transfer of carbon to the soil as litter and root turnover, contributes to accumulation of carbon in the soil (Leifeld and Kogel-Knabner, 2005) and lower soil carbon stock in the pine forest may be due to pine 


\section{International Journal of Science and Research (IJSR) \\ ISSN (Online): 2319-7064 \\ Index Copernicus Value (2015): 78.96 | Impact Factor (2015): 6.391}

species that retained carbon in the leaves for longer period of time than the deciduous tree species. In our studies the higher value of SOC stocks in the surface layer are consistent with $\mathrm{Fu}$ et al. (2010) which may be due to higher input of carbon to the surface litter layer, roots and roots debris. There is decrease of SOC stocks when primary forest is converted into secondary forest (Lal, 2004). If the secondary forest is well conserved and left for natural revegetation than the SOC stock can be recovered. Following deforestation and forest disturbances the increased presence of herbs and shrubs can alter the source of carbon input to the soil, leading to small, but significant changes in soil carbon and other soil nutrients. Sohrabi et al. (2016) have reported the potential soil carbon storage of the coniferous was less than that of the deciduous. This may be due to addition of fine roots into the soil resulting into carbon gain in the soil in deciduous (Waring and Running, 1998; Clark et al. 2001). In the present study the PPF has the least soil carbon stock as compared to other forest ecosystem as pine species has lesser fine roots than the deciduous species and slower strategy to development of fine roots systems. According to Law et al. (2001) the litter decomposition rate for coniferous is also slow. The impact of litter quality and litter carbon decay under the different land uses may cause variation in the soil carbon stock. However, Hansson(2011) have reported that litter inputs and litter carbon do not affect the soil carbon storage but play other important roles affecting nitrogen pool, soil fauna, soil acidity, mineral nutrients content in the soil. Aryal et al. (2013) have reported higher soil organic carbon in the mixed forest than the pine dominated forest with value $60.86 \pm 10.19$ and $44.19 \pm 6.02 \mathrm{t}$ $\mathrm{ha}^{-1}$ which is comparable with our results. Our findings were consistent with the findings as reported by Sheikh et al. (2009) with SOC higher in Quercus leucotrichophora forest (160.8 $\mathrm{t} \mathrm{ha}^{-1}-185.6 \mathrm{t} \mathrm{ha}^{-1}$ ) and lower SOC in Pinus roxburghii forest $91.24 \mathrm{t} \mathrm{ha}^{-1}-141.6 \mathrm{t} \mathrm{ha}^{-1}$ ) in Garhwal Himalaya.

The SOC stocks in our study (0.3 $\mathrm{m}$ depth) were compared with the values reported by Chhabra et al. (2003) for Indian forest (1m depth), $70 \mathrm{t} \mathrm{ha}^{-1}$ in tropical deciduous forest and $162 \mathrm{t} \mathrm{ha}^{-1}$ in montane temperate forest. Our finding of SOC stock in the UOF and DOF was comparable with the finding reported by Shrestha and Singh (2008) in mountainous watershed of Nepal, manage dense forest and SchimaCastanopsis forest $\left(0.7 \mathrm{~m}\right.$ depth) with values $70 \mathrm{t} \mathrm{ha}^{-1}$ and $103 \mathrm{t} \mathrm{ha}^{-1}$ respectively. Our SOC stock values lie between the finding reported by Baneerjee (2014) with the value ranging from $47.8-365.4$ tha $^{-1}$ in the different altitudinal gradients in Darjeeling Himalayan region and between 21.6$25 \mathrm{t} \mathrm{Cha}^{-1}$ in $0-15 \mathrm{~cm}$ soil depth under the planted tree fallows in Morogoro, Tanzania. Saha et al. (2010) have reported the total soil organic carbon pool ranging $(0-20 \mathrm{~cm}$ depth) from 28 to $37 \mathrm{t} \mathrm{ha}^{-1}$ for different land uses in Kerala which were lesser than our values. Djomo et al. (2011) have reported highest soil carbon stock in managed forest of south western Cameroon with the values $56 \mathrm{t} \mathrm{ha}^{-1}(0-15 \mathrm{~cm})$ and 27 $\mathrm{t} \mathrm{ha}^{-1}(15-30 \mathrm{~cm})$ which was comparable with our findings. Sreekanth et al.(2013) studied different percentage SOC content in different forests ecosystem of Chinnar wild life Sanctuary, Kerala and recorded maximum SOC in Shola forest $(4.56 \%)$ which may be attributed to evergreen closed canopy, luxuriant undergrowth and dense litter cover and minimum in the riparian forest $(3.32 \%)$ with the average
SOC content of $3.95 \%$ for bulk soil $(0-30 \mathrm{~cm})$. The 18 -yearold restored forest ecosystems in subtropical, China had a significant impact on soil chemical and biological properties as such conversion from conifer and conifer-broadleaf forest ecosystems to broadleaf forest ecosystems, SOC and others generally increased indicating that the broadleaf forest ecosystems and mixed broadleaf and coniferous species plantations have the potential role of degraded red soil restoration (Jiang et al. 2010). Our soil carbon stock 0-30 cm were comparable with the finding of Rabha et al. (2014) with SOC stock 35.67-57 $\mathrm{t} \mathrm{ha}(0-30 \mathrm{~cm})$ in four Dipterocarpus turbinatus dominated forest of Assam, Northeast India who reported that SOC ranged between 91.40-141.13 $\mathrm{t} \mathrm{ha}^{-1}$ in $1 \mathrm{~m}$ soil depth thus emphasizing the importance of this forest type in sequestering large amount carbon in soil and vegetation in spite of facing heavy biotic pressure. In the present study our DOF if left for natural regeneration and conservation will secure soil carbon. Plantation forests, due to uniformity of the stand structure, the above ground biomass carbon will be higher in comparison to soil (Lal and Singh, 2000). Ramesh et al. (2015) have evaluated four agroforestry systems Michelia oblonga, Parkia roxburghii, Alnus nepalensis and Pinus kesiya in Meghalaya, India and Alnus nepalensis recorded the highest mean SOC $60.2 \mathrm{t} \mathrm{ha}^{-1}$. Similarly, converting native vegetation to orchard or cropland had resulted in losses of $25-50 \%$ of SOC in the top $1 \mathrm{~m}$ as reported by Post and Kwon (2000) and similar outcome was observed in our orchard plantation which was natural forest originally. Mandal et al. (2012) studied the effects of cropping on soil properties and SOC stock in Deras region, India and the lowest SOC stock (11.81 t ha' $\left.\mathrm{th}^{-1}\right)$ in the soils of Guava orchard $0-15 \mathrm{~cm}, 16.08 \mathrm{t} \mathrm{ha}^{-1}$ in Mango Orchard in $15-30 \mathrm{~cm}$. The Mango and Guava orchard soils had 68.53 and $54.71 \mathrm{t} \mathrm{ha}^{-1}$ of SOC, respectively, in the $0-90 \mathrm{~cm}$ soil depth which was found to be lesser than our results in OPF. Our values were comparable with the report of Sharma et al. (2014) where they had studied the SOC in different land use system in the foothills of Himalayas and forest recorded the highest carbon stock of $47.5 \mathrm{t} \mathrm{ha}^{-1}$ followed by horticultural systems $42.4 \mathrm{t} \mathrm{ha}^{-1}$, degraded land $36.3 \mathrm{t} \mathrm{ha}^{-1}$ and agricultural land $35.1 \mathrm{t} \mathrm{ha}^{-1}$. Increase in carbon stock of forest soils can be achieved through forest management including site preparation, species selection, fertilizers and it is decreased through forest harvesting (Lal, 2005). Thus, emphasizing and encouraging for the orchard plantation and management in the future as important fruit trees plays an additional role in climate change mitigation by securing carbon in biomass and soil.

\section{Conclusion}

Results from this study have demonstrated that both the natural and human impacted land uses have significant impacts on the soil carbon stock and other soil nutrients. Secondary forest if well conserved and left for natural revegetation can serve as an important carbon sink in Senapati district. In terms of beneficial strategies Oak forest plays a better role in storing carbon than the pine forest. Orchard plantation should be encouraged as it not only benefited human directly but also plays the potential role in mitigating the climate change by securing the soil carbon. Oak species which is a common broad-leaf deciduous species is able to 


\section{International Journal of Science and Research (IJSR) \\ ISSN (Online): 2319-7064 \\ Index Copernicus Value (2015): 78.96 | Impact Factor (2015): 6.391}

establish across a wide range of environmental conditions of Senapati district, would shape contrasting patterns of carbon and nutrient cycling, nutrient availability and ecosystem structure and function.

\section{Acknowledgment}

We sincerely thank Department of Science and Technology, GOI (DST/IS-STAC/CO2-SR-226/14(G)-AICP-AFOLU-III) for financial assistance. The first author thanks ICAR, Imphal for allowing her to use their Soil Laboratory during soil analysis. We thank Head of the Department Life Sciences, Manipur University for providing us necessary facilities during our research work.

\section{References}

[1] Albaladejo J, Ortiz R, Garcia-Franco, N., RuizNavarro, A., Almagro, M., Garcia-Pintado, J and Martinez-Mena M. 2013. Land use and climate change impacts on soil organic carbon stocks in semi-arid Spain. J Soil Sediments 13(2):265-277

[2] Anderson J M and Ingram J S I.1993. Tropical Soil Biology and Fertility - A Handbook of Methods (2nd Edition) CAB International Wallingford UK.

[3] Aryal, S., Bhattarai, D. R and Devkota, R. P. 2013.comparison of soil stocks between mixed and pine-dominated forest stands within the Gwalinidaha community forest in Lalitpur. Small-scale forestry. 12:659-666

[4] Banerjee, S. K. 2014. Forest soil carbon stock along the altitudinal gradient in the Darjeeling Himalayan region. Indian Forester, 140(8): 775-779.

[5] Bray, R. H and Kurtz, L. T. 1945. Determination of total, organic, and available forms of phosphorus in soils. Soil Science, 59: 39-45.

[6] Campos, C. A., Aguilar, S. G. and Landgrave, R. 2014. Soil organic carbon stocks in Veracruz State (Mexico) estimated using the 1:250, 000 soil database of INEGI: biophysical contributions. J Soils Sediments. 14:860-871

[7] Champion, H.G \& Seth, S.K.1968: A revised survey of the forest types of India, New Delhi, India

[8] Chhabra, A and Dadhwal, V. K. 2004. Assessment of major pools and fluxes of carbon in Indian forests. Climatsic Change 64: 341-360.

[9] Chhabra, A, Palria, S and Dadhwal, V. K. 2003. Soil organic carbon pool in Indian forests. For. Ecol. Manage 173(1-3):187-199

[10]Chiti, T., Grieco, E., Perugini, L., Rey, A and Valentini, R. 2014. Effect of the replacement of tropical forests with tree plantations on soil organic carbon levels in the Jomoro district, Ghana. Plant Soil.375:4759

[11]Clark, D. A., Brown, S and Kicklighter, D. W. 2001. Measuring net primary production in forests: concepts and field methods. Ecological Applications, 11(2): $356-370$

[12]Dixon, R. K., Brown, S., Houghton, R. A., Solomon, A. M., Trexler, M. C and Wisniewski, J. 1994
Carbon pools and flux of global forest ecosystems. Science 263:185-191

[13]Djomo, A. N, Knohl, A and Gravenhorst, G. 2011. Estimations of total ecosystem carbon pools distribution and carbon biomass current annual increment of a moist tropical forest. Forest Ecology and Management. 261: 1448-1459

[14]

FAO. 2005. The importance of soil organic matter: key to drought-resistant soil and sustained food production, Soils Bulletin 80, FAO, Rome

[15]Fu, X., Shao, M., Wei, X and Horton, R. 2010. Soil organic carbon and total nitrogen as affected by vegetation types in northern Loess plateau of China.Geoderma.155:313-329

[16]Hansson, K. 2011. Impact of tree species on carbon in forest soils. Ph.D. Dissertation. Uppsala: Swedish University of Agricultural Sciences

[17]Hanway, J. J and Heidal, H.1952. Soil analysis methods as used in Lowa State Clloege. Agriculture Bulletin 57:1-13

[18]Houghton, R. A.2005. Aboveground forest biomass and Global carbon balance. Global Change biology.11:945-958

[19]IPCC.2000. Land use, Land use change and forestry. A special report of the IPCC. Cambridge University Press, Cambridge, p 377

[20]IPCC. 2007. Climate Change 2007.Synthesis report. Contribution of working Groups I, II and III to the fourth Assessment Report of the Intergovernmental panel on Climate Change. IPCC Geneva Switzerland [21]Jandl, R., Linder, M., Vesterdal, L., Bauwens, B., Baritz, B., Hagedorn, F., Johnson, D. W., Minkkinen, K., Byrne, K. A. 2007. How strongly can forest management influence soil carbon sequestration? Science Direct. Geoderma 137: 253-268

[22]

Jiang, Y. M, Chen, C. R., Liu, Y.Q and Xu, Z. H. 2010. Soil soluble organic carbon and nitrogen pools under mono- and mixed species forest ecosystems in subtropical china. J Soil Sediments. 10:1071-1081

[23]Jobbagy, E. G and Jackson, R. B. 2000. The vertical distribution of soil organic carbon and its relation to climate and vegetation. Ecological Applications 10, 423-436

[24]Laganiere, J, Angers, D and Pare, D. 2010 Carbon accumulation in agricultural soils after afforestation: a meta-analysis. Glob Chang Biol.16:439-453

[25]Lal, R.2005. Forest soils and carbon sequestration. For. Ecol. Manage .220, 242-258

[26]

Lal, R and Singh, R.2000. Carbon sequestration potential of Indian forest. Environmental monitoring and Assessment.60:315-327

[27]Lal, R. 2004. Soil carbon sequestration impacts on global climate change and food security.Science.304, 1623-1627

[28]Law, B. E., Thornton, P .E and Ervin, J. 2000. Carbon storage and fluxes in ponderosa pine forests at 


\section{International Journal of Science and Research (IJSR) \\ ISSN (Online): 2319-7064 \\ Index Copernicus Value (2015): 78.96 | Impact Factor (2015): 6.391}

different development stages. Global Change Biology. 7(7):755-777

[29]Leifeld, J. and Kögel-Knabner, I. 2005. Soil organic matter as early indicators for carbon stock changes under different land-use, Geoderma, 124, 143-155.

[30] Mandal, K. G., Baral, U., Padhi, J., Majhi, P., Chakarborty, $\mathrm{H}$ and Kumar, A.2012. Effects of cropping on soil properties and organic carbon stock in Deras region, India. Regional Environmental Change $12.4 ; 899-912$.

[31]Melvin, A M., Mack, M. C., Johnson, J. F., McGuire, A. D., Genet, H andSchuur, E. A G.2015. Differences in ecosystem carbon distribution and nutrient cycling linked to forest tree species composition in a mid-successional boreal forest. Ecosystems. 015-9912-7.

[32]Palmer, C. J., Smith, W. D and Conkling, B. L. 2002. Development of protocol for monitoring status and trends in forests soil carbon at a national level. Environmental Pollution. 116, S209-S219

[33]Post, W. M and Kwon, K. C. 2000. Soil carbon sequestration in different land use change: processes and potential. Glob Chang. Biol 6: 317-327

[34]Rabha, D., Borah, N., and Das, A.K. 2014. Assessment of aboveground and soil organic carbon stocks in Dipterocarpus forest of Barak valley, Assam, Northeast India. International journal of Ecology and Environmental Sciences 40(1): 29-40.

[35]Raich, J. W and Potter, C. S. 1995. Global patterns of carbon dioxide emissions from soils. Global Biochemical cycles 9, 23-26

[36]Ramesh, T., Manjaiah, K. M., Mohopatra, K. P and Rajasekar. K. 2015. Assessment of soil organic carbon stocks and fractions under different agroforestry systems in subtropical hill agro ecosystems of north-east India. Agroforest Syst. 89:677-690

[37]Saha, S. K, Nair, P. K. R., Nair, V. D and Kumar, B. M. 2010. Carbon storage in relation to soil sizefractions under tropical tree based land use systems. Plant Soils 328:433-446

[38]Scharlemann, J. P. W., Tanner, E.V. J., Hiederer, R and Kapos, V. 2014. Global soil carbon: understanding and managing the largest terrestrial carbon pool. Carbon management.5:1, 81-91.

[39]Sharma, V., Hussain, S., Sharma, K. R and Arya, V. M.2014.Labile carbon pools and soil organic carbon stocks in the foothill Himalayas under different land use systems.Geoderma 232-234:81-87

[40]Sheikh, M. A., Kumar, M and Bussmann, R.W. 2009. Altitudinal variation in soil organic carbon stock in coniferous sub-tropical and broadleaf temperate forests in Garhwal, Himalaya. Carbon balance and Management.4:8

[41]Shrestha, B. K., Sitaula, B. R., Singh, R and Bhatacharyya, M. 2004. Soil organic carbon stocks in soil aggregates under different landuse systems in Nepal. Nutr. Cycling Agroecosyst .70, 201-13

[42]

Shrestha, B. M and Singh, B. R. 2008. Soil and vegetation carbon pools in mountainous watershed of Nepal. NutrCyclAgroecosyst 81:179-191.

[43]Sohrabi, M., Bakhtiarvand-Baktiari, S and Ahmadi, K. 2016. Above- and below-ground biomass and carbon stocks of different tree plantations in central Iran. J Arid Land. 8(1): 138-145

[44]

Sreekanth, N. P., Prabha, P.V., Padmakumar, B and Thomas, A.P. 2013. Soil carbon alteration of selected forest types as an environmental feedback to climate change. International journal of Environmental Sciences. 3.5

[45]Subbaiah, B .V and Asija, G. L.1956.A Rapid Procedure for Determination of Available Nitrogen in Soil, Current Science 25, 259-260

[46]Tate, K. R., Scott, N. A., Ross, D. J., Parshotam, A and Claydon, J.J. 2000. Plant effects on soil carbon storage and turnover in a montane beech (Nothofagus) forest and adjacent tussock grassland in New Zealand. Aust J Soil Res 38:685-698.

[47]

Trumbore, S. E. 1997. Potential responses of soil organic carbon to global environmental change. P Natl A Sci USA 94:8284-8291.

[48]Walkly, A. and Black, I. A. 1934. An examination of Degtjareff method for determining soil organic matter and a proposed modification of the chromic acid titration method. Soil Sci. 37: 29-37.

[49]Waring, R. H and Running, S. W. 1998. Forest Ecosystem: Analysis at multiple Scales. U.K: Elsevier Academic press.

[50]Xu, X., Liu, W., Zhang, C and Kiely, G. 2011. Estimation of soil organic carbon stock and its spatial distribution in the republic of Ireland. Soil Uses and Management.1475-2743. 